\author{
A.В. Рябуха
ЛІТОЛОГІЧНІ КОМПЛЕКСИ НИЖНЬОЇ КРЕЙДИ ПІВНІЧНО-ЗАХІДНОГО ШЕЛЬФУ ЧОРНОГО МОРЯ

\title{
A.V. Ryabukha \\ LITHOLOGICAL COMPLEXES OF THE LOWER CRETACEOUS OF NORTH-WESTERN BLACK SEA SHELF
}

На основі літологічних досліджень фактичного матеріалу була встановлена велика різноманітність осадових порід нижньої крейди північно-західного шельфу Чорного моря. За результатами літолого-фаціального аналізу, були виділені чотири літологічні комплекси з трьох серій. Найбільше поширення отримала аргілітова серія, підпорядкований характер мають псамітова серія та змішана псаміто-карбонатно-аргілітова серія.

Ключові слова: осадові породи, літологічний комплекс, Чорне море, шельф, нижня крейда.

\begin{abstract}
На основании литологических исследований фактического материала было установлено большое разнообразие осадочных пород нижнего мела северо-западного шельфа Черного моря. Используя литолого-фациальный анализ, были выделены четыре литологических комплекса из трёх серий. Наибольшее распространение получила аргиллитовая серия, подчиненный характер носят псаммитовая серия и смешанная псаммито-карбонатно-аргиллитовая серия. Ключевые слова: осадочные породы, литологический комплекс, Черное море, шельф, нижний мел.
\end{abstract}

Based on lithological research of factual data it was determined considerable variety of the Lower Cretaceous sedimentary rocks of the north-western Black Sea shelf. Using the litho-facial analysis, there were identified four lithological complexes of three series. Argillaceous series have the largest distribution, psammitic series and composite psammitic-carbonateargillaceous series have subordinate disposition.

Keywords: sedimentary rocks, lithological complex, Black Sea, shelf, Lower Cretaceous.

\section{ВСТУП}

Особливості геологічної будови нижньокрейдових утворень Чорноморсько-Кримського осадового басейну в різних його частинах вивчені неоднаково. Найбільш детально вони досліджені в межах Рівнинного Криму, Західного та Північного Причорномор'я, а найменше - у межах акваторії північно-західного шельфу Чорного моря. Більшість дослідників, серед яких О.Т. Богаєць, М.І. Євдощук, П.М. Мельничук, М.І. Павлюк, Б.М. Полухтович та ін., розглядають нижньокрейдовий комплекс ПричорноморськоКримського регіону як один з основних об'єктів пошуків скупчень вуглеводнів у межах суходолу і морських акваторій півдня України. Їхня продуктивність доведена бурінням у Рівнинному Криму, північно-західному Передкавказзі та на прилеглому румунському шельфі Чорного моря.

\section{РАЙОН РОБІТ І ОБ'ЄКТ ДОСЛІДЖЕННЯ}

В межах північно-західного шельфу Чорного моря нижньокрейдові утворення розкриті на таких площах: Безіменна, Гамбурцева, ПівденноГоліцинська, Десантна, Євпаторійська, Іллічівська, Одеська, Олімпійська, Прадніпровська, Південно-Бортова, Флангова (рис. 1). Найбільш повний розріз потужністю понад 1300 м представлений лише в межах Олімпійської структури і складений алевроглинистою товщею (аргіліти, малопотужні прошарки алевролітів) з підпорядкованими пачками псамітів. А на інших площах нижня крейда представлена головним чином верхнім альбом, у якому було призупинено більшість свердловин. Розглянемо літологічні особливості двох товщ: верхнього барему - апту та верхнього альбу. В основу досліджень було покладено метод кількісного літолого-фаціального аналізу, що дало змогу виявити участь окремих літотипів теригенних і карбонатних порід у будові товщ, встановити особливості їх просторового поширення в межах досліджуваної території. Для цього були вивчені та проаналізовані розрізи нижньокрейдових відкладів, розкритих глибокими свердловинами.

\section{РЕЗУЛЬТАТИ ТА ЇХ АНАЛІЗ}

При детальному вивченні порід нижньої крейди було встановлено їх значну різноманітність. Розглянемо речовинно-генетичні типи порід нижньої крейди, які представлені в розрізах зазначених структур північно-західного шельфу Чорного моря. 


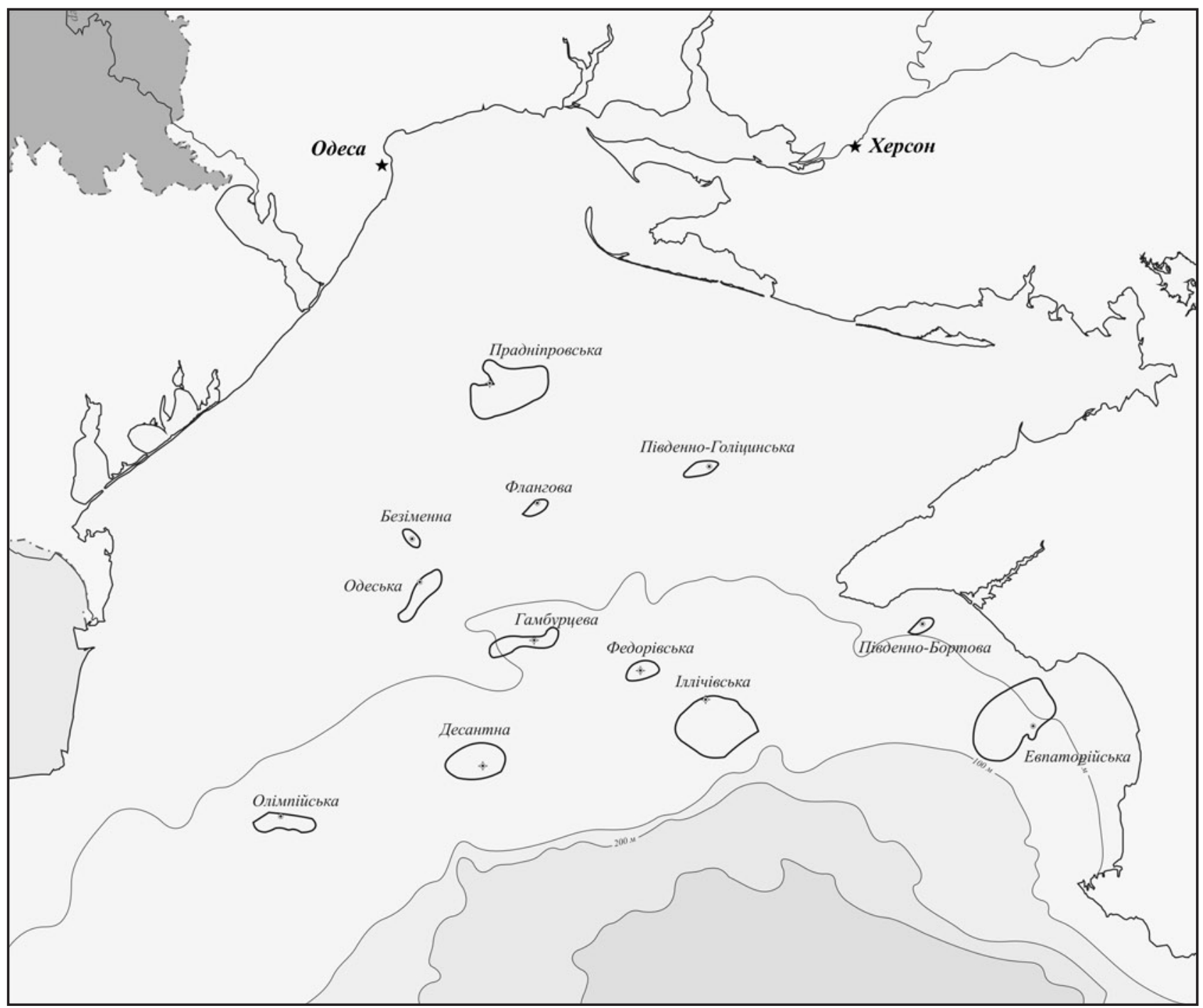

Рис. 1. Схема структур північно-західного шельфу Чорного моря

Вапняково-глинисті дрібнозернисті пісковики трапляються на Олімпійській структурі в породах барему. Для них характерні орієнтована мікротекстура і велика кількість акцесорних мінералів - циркону, рутилу, хлориту, звичайної рогової обманки, турмаліну, сфену, гранату (альмандину), рудних та ін. У них також спостерігаються численні субпаралельні ниткоподібні прожилки бітумоїдів темно-брунатного кольоpy.

Різнозернисті кальцито-каолінітові пісковики, з погано відсортованим уламковим матеріалом трапляються на Десантному піднятті у відкладах альбу. Породи складені кородованими уламковими зернами кутастої форми. Серед них переважають польові шпати, перш за все альбіт, зерна яких зазнали помітних процесів змін. До 40\% об'єму породи складають уламки ефузивних і осадових порід, зрідка метаморфічних кварцитів. Спостерігається мінливий вміст великих, часто деформованих лусочок біотиту бурувато-коричневого кольору довжиною до 2 мм, які розміщені субпаралельно. В пісковиках відмічається повсюдне підвищення вмісту піриту і бітумоїдів.

Вапнякові і глинисті дрібно- і крупнозернисті гравійні пісковики з поганою відсортованістю уламкового матеріалу були описані на Іллічівській і Фланговій структурах. Вони містять до 30\% уламків метаморфічних кварцитів. У них спостерігається збагачення різною мірою мікрозернистим сидеритом, піритом і пластівчастими бітумоїдами, а також присутня помітна кількість вуглефікованих рослинних залишок.

Алевроліти вапнякові і вапняково-глинисті, сірі, для яких характерна орієнтована мікротекстура, мають широке розповсюдження. Серед уламкового матеріалу переважають кутасті зерна кварцу, підпорядкований характер мають зерна польових шпатів, які звичайно не зазнавали процесів змін. У породах присутні кутасті уламки (до 10\%), які представлені ме- 
таморфічними кварцитами, ефузивами, слюдистими сланцями. Спостерігається помітний вміст мусковіту і деформованих лусочок біотиту. Алевроліти збагачені піритом і дисперсними бітумоїдами, містять вуглефіковані рослинні залишки. Вони трапляються в усіх трьох ярусах на багатьох підняттях (Олімпійське, Гамбурцева, Флангове, Десантне).

Алевроліти і псамоалевроліти також складені погано відсортованим теригенним матеріалом. Для них характерна нечітко орієнтована мікротекстура. Спостерігається збагачення часто деформованими лусочками мусковіту довжиною до 0,5 мм. Помітну домішку складають уламки метаморфічних кварцитів і ефузивних порід. Лімоніт виступає в ролі цементу контактнопорового типу. Його вміст у породі зменшується по розрізу знизу вверх, і тоді між зернами і в порах спостерігається зернистий кальцит і глиниста речовина. Часто присутні вуглефіковані рослинні залишки.

Кварцево-слюдисті кальцит-лімонітові породи, які при макроскопічному опису були прийняті за червоноколірні міцні аргіліти, трапляються в породах альбу на Одеській і Безіменній площах. Для них характерна різко виражена хаотична з елементами завихрень мікротекстура. Уламкові зерна понад 0,1 мм мають нерівномірне розповсюдження в породі, невідсортовані і необкатані. В кількості 30\% присутні уламки метаморфічних кварцитів, ефузивів і осадових порід, які різною мірою точково кородовані зеленим глауконітом. Породи збагачені бітумоїдами, які утворюють численні субпаралельні прожилки.

Глини сірі і темно-сірі, алевритисті, вапняковисті, тонкошаруваті, ущільнені трапляються повсюдно в усіх трьох ярусах нижньої крейди на Олімпійському піднятті. А на Одеському в породах альбу були описані доломітові глини, в яких доломіт представлений у вигляді зерен розміром 0,02-0,08 мм і ромбоедричними кристалами розміром до 0,2 мм.

Аргіліти дуже поширені і часто трапляються на багатьох підняттях. Так, вапнякові каолінітсерицитові аргіліти виявлені у відкладах барему на Олімпійській структурі, а в товщі альбу тут же спостерігаються чорні безкарбонатні аргіліти.

Вапняково-слюдисті аргіліти темно-сірого кольору часто збагачені мікрозернистим сидеритом, рідше уламковими зернами розміром 0,02-0,05 мм. Для них характерний дуже високий вміст бітумоїдів у вигляді численних субпа- ралельних лінзочок і вуглефікованих рослинних залишок. Трапляються вони в товщі альбу на Десантній і Південо-Голіцинській площах.

На Іллічівській структурі такожописані темносірі алевритисті аргіліти, в яких спостерігається високій вміст мікрозернистого сидериту, піриту і пластівчастих бітумоїдів та помітна кількість вуглефікованих рослинних залишок.

Вапняки глинисті від світлих до темних відтінків сірого кольору трапляються в усіх ярусах на Олімпійській, Гамбурцева і ПівденноГоліцинській площах. Для них характерна орієнтована мікротекстура і високий вміст органогенних решток, серед яких присутні черепашки форамініфер планктонного типу та їх детрит, уламки черепашок молюсків, уламки моховаток та голкошкірих. Рідко спостерігаються вапняки складені більш ніж на 40\% голчастими спікулами губок. Породоутворюючий мінерал представлений мікрозернистим кальцитом, який виступає або в ролі цементу, або як основна маса породи залежно від кількості органогенних решток. В породі спостерігається достатньо багато піриту, який приурочений до бітумоїдів. Вони, в свою чергу, є двох видів - субпаралельні ниткоподібні прожилки темно-брунатного кольору і грудкуваті бурого кольору.

Глинисті доломіти зцементовані глинистою речовиною і лімонітом, які мають вигляд приховано кристалічної маси. Іноді доломіт утворює скупчення зерен і кристалів самої різноманітної форми майже без цементу. Спостерігаються вони лише на Одеському піднятті в утвореннях альбу.

Вулканічні туфи, в яких численні порфіробласти зцементовані каолінітом, спочатку були описані як діабазові й андезитові порфірити. Для них характерний мінливий вміст, місцями аж до збагачення, мікрозернистого сидериту у вигляді грудкуватих утворень. Трапляються вони в породах альбу на Одеському і, можливо, Федорівському підняттях.

За співвідношенням чотирьох формуючих компонентів: пісковики - алевроліти - аргіліти - карбонатні породи, згідно з методикою кількісного літолого-фаціального аналізу [2], в розрізі верхньоготерив-аптської товщі Чорноморсько-Кримського регіону прогнозується розвиток шести літологічних серій [1], що наведені на рис. 2: аргіліто-алевролітопсамітовий та аргіліто-карбонатно-псамітовий комплекси псамітової серії; змішана псамітоалевроліто-аргілітова; змішана псаміто- 


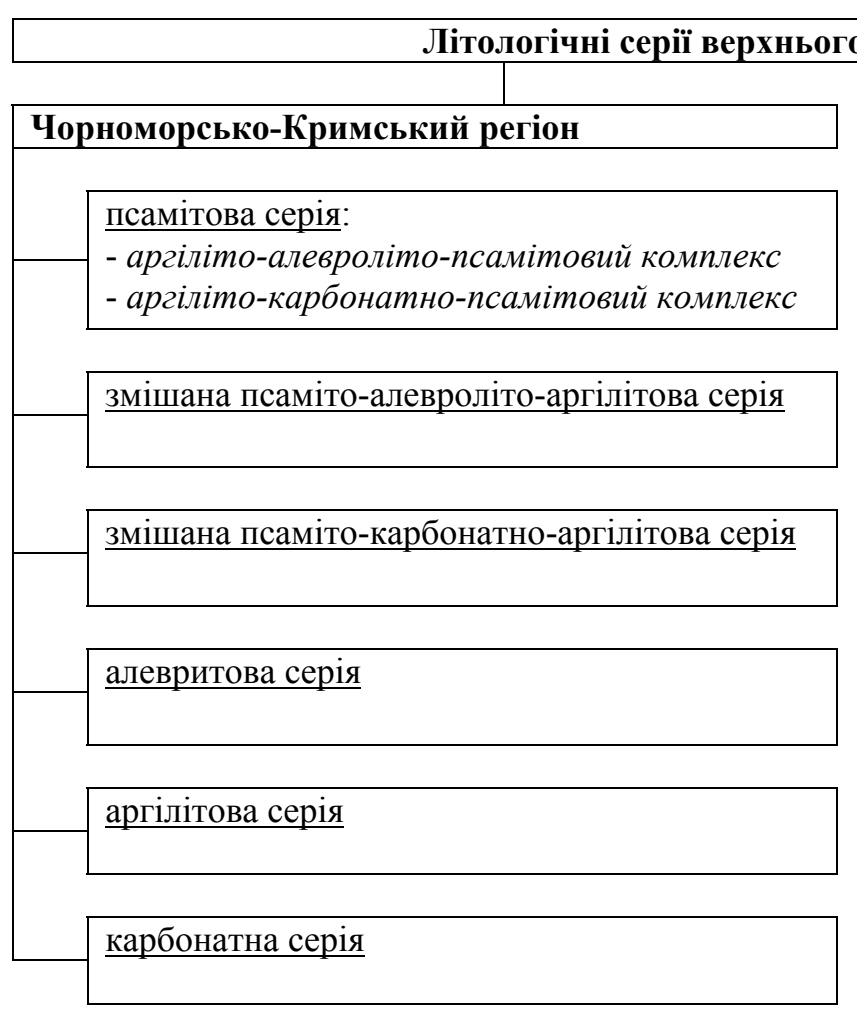

Рис. 2. Схема літологічних серій і комплексів верхньоготерив-аптської товщі

карбонатно-аргілітова; алевритова; аргілітова та карбонатна.

В розрізі верхньобарем-аптської товщі для північно-західного шельфу достовірно можна встановити аргілітову серію (пісковики 0-25\%, алевроліти - 0-25\%, аргіліти - 75$100 \%)$, що має значну площу розповсюдження на південному борту валу Губкіна і прогнозується далі на схід вузькою смугою, що облямовує Каламітське піднятя. Комплекс характеризується відкладами верхнього барему - апту, які були розкриті, за даними Л.Ф. Плотнікової [3, 4], свердловиною Олімпійська-400 в інтервалі глибин 2696-3748 м.

За даними мінерало-петрографічних досліджень відклади представлені перешаруванням аргілітів та алевролітів, в яких рідкотрапляються прошарки пісковиків. На сьогодні максимальна розвідана потужність верхньобарем-аптських утворень на шельфі становить 1050 м.

Також до відкладів барему, за визначеннями В.Г. Дулуб, відносять піщані утворення, розкриті у свердловині Прадніпровська-2 на глибині 2150-2190 м, які підтверджують розвиток аргіліто-карбонатно-псамітового комплексу псамітової серії (пісковики - 50-75\%, карбонатні породи - 25-50\%, аргіліти - 0-25\%) на заході регіону (Криловський прогин).

У складі верхньоальбської товщі Чорномор-
сько-Кримського регіону виділено сім літологічних комплексів з п'яти серій [1], що наведені на рис. 3. Зокрема такі: псамітовий з прошарками алевролітів та аргілітів комплекс псамітової серії; переважно псаміто-кременистий комплекс змішаної псаміто-кременисто-аргілітової серії; кременистий комплекс кременистої серії; переважно псаміто-аргілітовий та переважно карбонатно-аргілітовий комплекси змішаної псаміто-карбонатно-аргілітової серії; псамітокременисто-аргілітовий та аргілітовий 3 прошарками алевролітів та псамітів комплекси аргілітової серії.

у товщі верхнього альбу на північнозахідному шельфі найбільше поширений аргілітовий комплекс 3 прошарками алевролітів та псамітів (пісковики - 0-25\%, алевроліти - 0-25\%, аргіліти - 50-75\%) аргілітової серії, потужність якого варіює від 100 до 1000 м. Його розповсюдження прогнозується у центральній, південній і східній частинах території. У свердловині Олімпійська-400 в інтервалі 2476-2696 м розкриті вапнисті глини і безкарбонатні аргіліти з прошарками вапнистих алевритів, які датуються середнім(?)-пізнім альбом.

У свердловинах Десантна-1 (2598-3125 м), Іллічівська-2 (2227-2531 м), Одеська-2(30773200 м), Південно-Голіцинська-3 (44504626 м), Євпаторійська-2 (514-710 м) роз- 


\begin{tabular}{|c|c|}
\hline \multicolumn{2}{|c|}{ Літологічні серії верхньоальбської товщі } \\
\hline Чорноморсько-Кримський регіон & Північно-західний шельф Чорного моря \\
\hline $\begin{array}{l}\text { псамітова серія: } \\
\text { - псамітовий з прошарками алевролітів та } \\
\text { аргілітів комплекс }\end{array}$ & $\begin{array}{l}\text { псамітова серія: } \\
\text { - псамітовий з прошарками алевролітів } \\
\text { та аргілітів комплекс }\end{array}$ \\
\hline $\begin{array}{l}\text { змішана псаміто-кременисто-аргілітова серія: } \\
\text { - переважно псаміто-кременистий комплекс }\end{array}$ & $\begin{array}{l}\text { змішана псаміто-карбонатно-аргілітова } \\
\text { серія: } \\
\text { - переважно карбонатно-аргілітовий } \\
\text { комплекс }\end{array}$ \\
\hline $\begin{array}{l}\text { кремениста серія: } \\
\text { - кременистий комплекс }\end{array}$ & $\begin{array}{l}\text { аргілітова серія: } \\
\text { - аргілітовий з прошарками алевролітів } \\
\text { та псамітів комплекс }\end{array}$ \\
\hline $\begin{array}{l}\text { змішана псаміто-карбонатно-аргілітова серія: } \\
\text { - переважно псаміто-аргілітовий комплекс } \\
\text { - переважно карбонатно-аргілітовий } \\
\text { комплекс }\end{array}$ & \\
\hline $\begin{array}{l}\text { аргілітова серія: } \\
\text { - псаміто-кременисто-аргілітовий комплекс } \\
\text { - аргілітовий з промарками алевролітів та } \\
\text { псамітів комплекс }\end{array}$ & \\
\hline
\end{tabular}

Рис. 3. Схема літологічних серій і комплексів верхньоальбської товщі

криті відклади верхнього альбу. У будові даного комплексу в основному приймають участь аргіліти та глини, які відрізняються за вмістом карбонатної та кременевої складових, із включеннями прошарків псамітів, алевритів та карбонатних порід.

У центральній частині попереднього літологічного комплексу у вигляді ізометричної плями виділяється переважно карбонатно-аргілітовий комплекс (пісковики - 0-25\%, карбонатні породи - 25-50\%, аргіліти - 25-50\%) змішаної псаміто-карбонатно-аргілітової серії. Відклади представлені декількома літологічними пачками; в нижній частині це аргіліти із малопотужними прошарками пісковиків та аргілітів, що змінюються вверх по розрізу пачкою вапняків та мергелів. По всьому розрізу трапляються малопотужні прошарки вулканогенноосадових утворень. Породи комплексу виявлені у свердловині Гамбурцева-2 (3480-3505 м) та у свердловинах Південно-Голіцинська-3 та Євпаторійська-2, де вони у середині верхньоальбського розрізу частково заміщують комп- лекс аргілітовий з прошарками алевролітів та псамітів.

На заході району у вигляді смуги субмеридіонального простягання поширений псамітовий з прошарками алевролітів та аргілітів комплекс (пісковики - 50-75\%, алевроліти - 0-25\%, аргіліти - 0-25\%) псамітової серії, який розкритий у свердловинах Безіменна-2 (21822258 м) і Флангова-2 (3260-3300 м). Комплекс представлений крупнозернистими пісковиками з включеннями гальок підстеляючих утворень, що заміщуються вище по розрізу більш дрібнозернистими різновидами. Прошарки алевролітів та аргілітів характерні для середньої частини розрізу, а малопотужні прошарки карбонатних порід простежуються у верхній частині.

\section{ВИСНОВКИ}

Встановлено велику різноманітність осадових порід нижньої крейди північно-західного шельфу Чорного моря, які представлені різноманітними за складом пісковиками, алевролітами, кварцево-слюдистими кальцит-лімонітовими 
породами, глинами, аргілітами, вапняками, доломітами і вулканічними туфами.

Нижньокрейдовий комплекс осадових порід поділяється на дві товщі: верхньобарем-аптську та верхньоальбську. Відклади барему та апту встановлені на двох площах, де представлені аргілітовою серією (Олімпійська площа) і аргіліто-карбонатно-псамітовим комплексом псамітової серії (Прадніпровська площа).

Верхньоальбська товща розкрита на 11 структурах та має більшу різноманітність. Охарактеризована трьома комплексами, а саме: аргілітовим комплексом з прошарками алевролітів та псамітів аргілітової серії (Олімпійська, Десантна, Іллічівська, Одеська, Південно-Голіцинська, Євпаторійська); переважно карбонатно-аргілітовим комплексом змішаної псаміто-карбонатно-аргілітової серії (Гамбурцева, Південно-Голіцинська, Євпаторійська); псамітовим з прошарками алевролітів та аргілітів комплексом псамітової серії (Безіменна, Флангова).

На таких площах, як Одеська, Іллічівська, Південно-Бортова, Федорівська, сутє- ву роль у розрізі верхнього альбу відіграють вулканогенно-осадові породи, але в окремий літологічний комплекс вони не виділяються.

1. Гнідець В.П., Григорчук К.Г., Захарчук С.М. та ін. Нафтогазоперспективні об'єкти України. Геологія нижньої крейди Причорноморсько-Кримської нафтогазоносної області. - К.: ЕКМО, 2010. - 247 с.

2. Киселев А.Е., Кульчицкий Я.О. Количественный метод в литологических исследованиях (на примере ЛеноВилюйской и Карпатской нефтегазоносных провинций) // Геол. журн. - 1983. - № 6. - С. 1-10.

3. Плотнікова Л.Ф., Іванік М.М., Шумник А.В. Стратиграфічне розчленування і історія розвитку морського басейну західної частини північно-західного шельфу Чорного моря в ранньокрейдовий час // Теоретичні та прикладні аспекти сучасної біостратиграфії фанерозою України. - К., 2003. - С. 165-168.

4. Плотнікова Л.Ф., Якушин Л.М., Іщенко І.І. Детальна стратифікація нижньокрейдових відкладів північнозахідного шельфу Чорного моря // Біостратиграфічні критерії розчленування та кореляція відкладів фанерозою України: Зб. наук. пр. ІГН НАН України. - К., 2005. - С. 75-79.

Інститут геологічних наук НАН України, Київ

Рецензент - чл.-кор. НАН України О.Ю. Митропольський 